\title{
Immunostaining of Cryptosporidiosis with Human Immunodeficiency Virus Infection
}

\author{
Eisuke Adachi ${ }^{1}$, Yasutoshi Kido ${ }^{1,2}$, Yasunori Ota ${ }^{3}$ and Tomohiko Koibuchi ${ }^{1}$
}

Key words: cryptosporidium, immunostaining, human immunodeficiency virus

(Intern Med 55: 3229-3230, 2016)

(DOI: 10.2169/internalmedicine.55.7246)

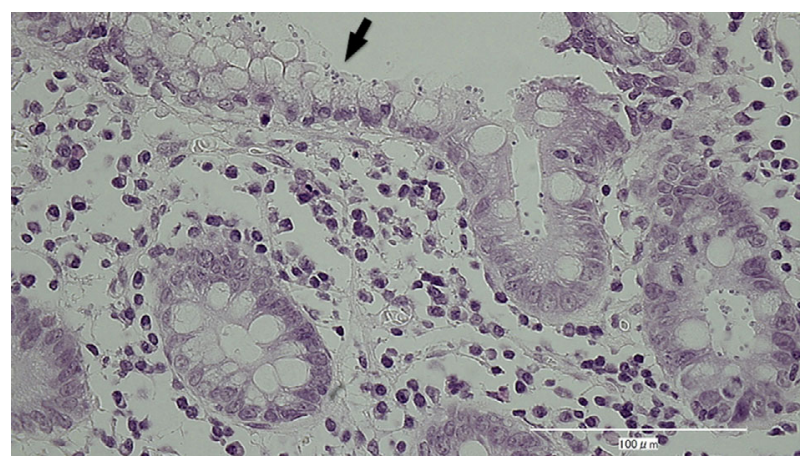

Picture 1.

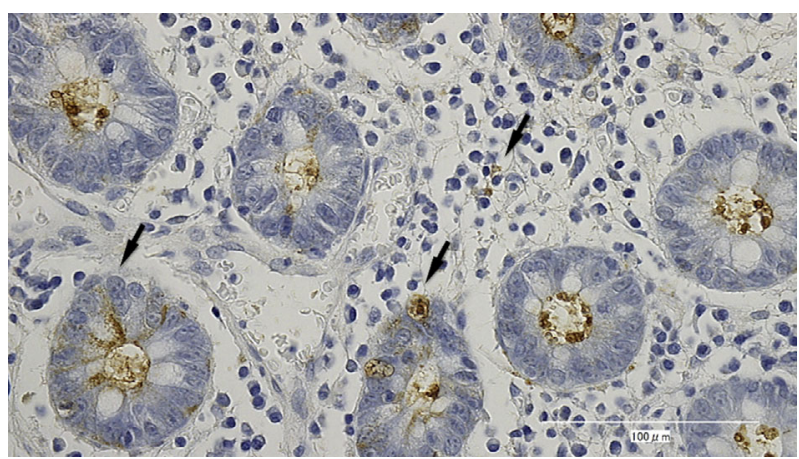

Picture 3.

A 33-year-old man with human immunodeficiency virus (HIV) infection was referred to our hospital because of profuse diarrhea and weight loss (Body mass index 14.5). The HIV-RNA and CD4 counts were 640,000 copies/mL and 22/ $\mu \mathrm{L}$, respectively. Hematoxylin and Eosin stained colonic biopsy specimens showed Cryptosporidium oocysts attached to the epithelial cells (Picture 1). On immunostained tissue specimens with anti-Cryptosporidium antibodies, parasites

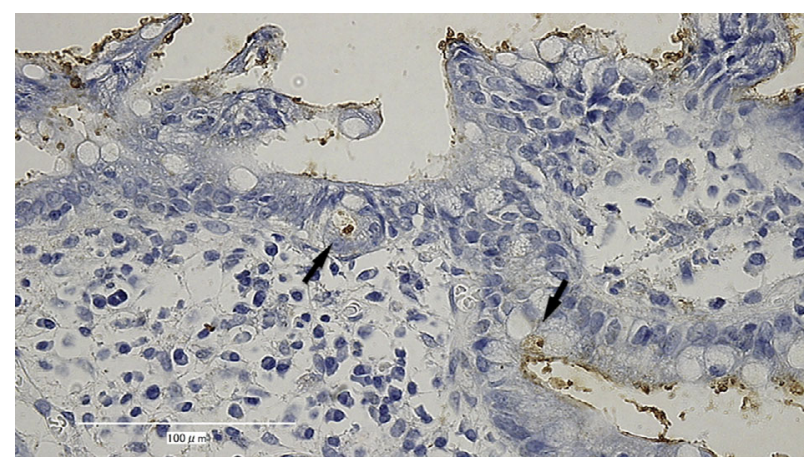

Picture 2.

were found to be penetrating the mucosal epithelium and they were also observed in the lamina propria (Picture 2, 3). Notably, the parasites were more abundant right under the damaged mucosal surface (Picture 3). His diarrhea improved 2 weeks after the initiation of antiretroviral therapy. These findings may indicate that HIV-associated mucosal immune dysfunction can sometimes lead to the onset of invasive cryptosporidiosis (1). Although immunological diagnostic stool tests are well documented (2), histological examinations in such cases are rarely performed. Immunostaining may therefore be a powerful tool to elucidate the mechanisms by which Cryptosporidium cause life-threatening diarrhea in HIV-infected patients.

The authors state that they have no Conflict of Interest (COI).

\section{References}

1. O'Hara SP, Small AJ, Nelson JB, et al. The human immunodeficiency virus type 1 tat protein enhances Cryptosporidium parvuminduced apoptosis in cholangiocytes via a Fas ligand-dependent

${ }^{1}$ Department of Infectious Diseases and Applied Immunology, IMSUT Hospital of The Institute of Medical Science, The University of Tokyo, Japan, ${ }^{2}$ Department of Biomedical Chemistry, Graduate School of Medicine, The University of Tokyo, Japan and ${ }^{3}$ Department of Pathology, IMSUT Hospital of The Institute of Medical Science, The University of Tokyo, Japan Received for publication February 8, 2016; Accepted for publication February 9, 2016 Correspondence to Dr. Eisuke Adachi, eadachi-ims@umin.ac.jp 
Intern Med 55: 3229-3230, 2016 DOI: 10.2169/internalmedicine.55.7246

mechanism. Infect Immun 75: 684-696, 2007.

2. Weber R, Bryan RT, Bishop HS, Wahlquist SP, Sullivan JJ, Juranek DD. Threshold of detection of Cryptosporidium oocysts in human stool specimens: evidence for low sensitivity of current diagnostic methods. J Clin Microbiol 29: 1323-1327, 1991.
The Internal Medicine is an Open Access article distributed under the Creative Commons Attribution-NonCommercial-NoDerivatives 4.0 International License. To view the details of this license, please visit (https://creativecommons.org/licenses/ by-nc-nd/4.0/).

(C) 2016 The Japanese Society of Internal Medicine http://www.naika.or.jp/imonline/index.html 